\title{
UNSUR PEMBENTUK FRASA EKSOSENTRIS DALAM HIKAYAT HANG TUAH
}

\author{
${ }^{1}$ Kartika Bintari dan ${ }^{2}$ Sumarlam \\ ${ }^{1}$ Program Studi Linguistik Deskriptif, Pascasarjana Universitas Sebelas Maret Surakarta, Indonesia \\ ${ }^{2}$ Fakultas Ilmu Budaya, Universitas Sebelas Maret Surakarta, Indonesia \\ Jalan Ir. Sutami No.36 A, Pucangsawit, Jebres, Surakarta, Jawa Tengah 57126 \\ Surel: kartikabintari@gmail.com
}

Informasi Artikel:

Dikirim: 24 Juni 2019 ; Direvisi: 19 Juli 2019; Diterima: 24 Juli 2019

DOI: 10.26858 /retorika.v12i2.9468

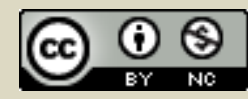

RETORIKA: Jurnal Bahasa, Sastra dan Pengajarannya berada di bawah lisensi

Creative Commons Attribution-NonCommercial 4.0 International License.

ISSN: 2614-2716 (cetak), ISSN: 2301-4768 (daring)

http://ojs.unm.ac.id/retorika

\begin{abstract}
Exocentric Phrase Forming Elements in Hikayat Hang Tuah. The purpose of this study was to describe the exocentric phrase forming elements in Hikayat Hang Tuah. This type of research is descriptive qualitative with the object of research in the form of phrases in Hikayat Hang Tuah. The data in this study are sentences containing exocentric phrases from data sources in the form of Hikayat Hang Tuah book documents. Observation techniques are used in data collection techniques, while the data analysis method in this study is the agih method with techniques for direct elements as a basic technique and advanced techniques in the form of sloping techniques. In Hikayat Hang Tuah there are three types of exocentric phrases (1) exocentric phrases directive with phrase-forming elements in the form of prepositions+nouns; (2) nondirective exocentric phrases with phrase-forming elements, namely particles/designations +adjectives and particles/word designations+nouns; and (3) connective exocentric phrases which form the phrase in the form of conjunctions+verbs. The diversity of linguistic elements in Hikayat Hang Tuah shows the manifestation of literary works as a manifestation of the richness of language.
\end{abstract}

Kata kunci: phrase elements, exocentric phrase, saga of Hang Tuah

Abstrak: Unsur Pembentuk Frasa Eksosentris dalam Hikayat Hang Tuah. Tujuan penelitian ini adalah mendeskripsikan unsur pembentuk frasa eksosentris dalam Hikayat Hang Tuah. Jenis penelitian ini ialah deskriptif kualitatif dengan objek penelitian berupa frasa dalam Hikayat Hang Tuah. Data dalam penelitian ini berupa kalimat yang mengandung frasa eksosentris dari sumber data berupa dokumen buku Hikayat Hang Tuah. Teknik observasi digunakan dalam teknik pengumpulan data, sedangkan metode analisis data dalam penelitian ini adalah metode agih dengan teknik bagi unsur langsung sebagai teknik dasar dan teknik lanjutan berupa teknik lesap. Dalam Hikayat Hang Tuah ditemukan tiga jenis frasa eksosentris (1) frasa eksosentris direktif dengan unsur pembentuk frasa berupa preposisi+nomina; (2) frasa eksosentris nondirektif dengan unsur pembentuk frasa, yaitu partikel/kata sebutan+adjektiva dan partikel/kata sebutan+nomina; dan (3) frasa eksosentris konektif yang unsur pembentuk frasanya berupa kata penghubung+verba. Keberagaman unsur kebahasaan dalam Hikayat Hang Tuah menunjukkan adanya manifestasi karya sastra sebagai perwujudan kekayaan bahasa.

Kata kunci: unsur frasa, frasa eksosentris, hikayat Hang Tuah 

Hikayat Hang Tuah merupakan hikayat yang telah melegenda sebagai pahlawan Melayu masa pemerintahan Sultan Melaka abad ke-15. Buku Hikayat Hang Tuah ditulis oleh Bot Genoot Schap yang diterbitkan oleh Pusat Bahasa Kementerian Pendidikan Nasional tahun 2010. Hikayat Hang Tuah berisi mengenai Raja Bintan, Hang Tuah lima bersahabat menjadi pegawai Raja, Kedatangan orang Jawa ke tanah Melayu, Raja Melaka dengan Raja Muda, Raja Melaka jadi Raja Keling, Hang Tuah diutus ke Majapahit, Hang Tuah digelar Laksamana, Patih Gajah Mada hendak membunuh Laksamana, Laksamana melarikan Tun Teja, Laksamana menyerang Megat Panji Alam di Inderapura, dan Laksamana diutus sekali lagi ke Majapahit.

Secara ringkas, Hikayat Hang Tuah menceritakan Laksamana yang lahir dari Ibu bernama Dang Merduwati dan ayah yang bernama Hang Mahmud. Hang Tuah hidup sederhana di Pulau Bintan bersama orang tua dan lima sahabatnya, yaitu Hang Jebat, Hang Kesturi, Hang Lekir, dan Hang Lekiu. Hang Tuah melawan perampok yang mengaku berasal dari daerah Siantan dan Jemaja atas perintah Gajah Mada di Majapahit. Keberanian Hang Tuah juga terbukti ketika melawan orang yang mengamuk di pasar. Kabar keberanian Hang Tuah sampai kepada raja dan raja mengangkat Hang Tuah menjadi biduanistara (pelayan raja). Gelar Laksamana diperoleh oleh Hang Tuah setelah menyelesaikan tugas untuk menyerang ke Palembang. Raja sering memerintahkan Hang Tuah ke Tiongkok, Rum, Mahapahit, dan dia pernah pula naik haji. Akhir hayat Hang Tuah berkhalwat di Tanjung Jingara.

Hikayat merupakan karya sastra yang menjadi pembangun kebudayaan sebagai manifestasi kehidupan jiwa bangsa dari abad ke abad dan akan menjadi peninggalan kebudayaan yang sangat tinggi nilainya. Schap (2010:v) menyatakan bahwa sejak abad ketujuh bahasa Melayu digunakan sebagai bahasa resmi di kepulauan Indonesia. Hal ini dapat dilihat pada prasastiprasasti Melayu-Kuno yang tersebar di Pulau Jawa, Sumatra, dan Kepulauan Riau. Bahasa Melayu sudah memegang peranan penting sebagai pendukung kebudayaan di Indonesia dan juga di Semenanjung Malaka.

Dengan demikian, penelitian ini memilih Hikayat Hang Tuah karena karya sastra berupa hikayat sudah menjadi pembangun kebudayaan dari abad ke abad dan akan menjadi peninggalan kebudayaan yang sangat tinggi nilainya. Selain itu, sejak abad ketujuh bahasa Melayu diguna- kan sebagai bahasa resmi di kepulauan Indonesia. Hikayat Hang Tuah merupakan hikayat yang sudah banyak dikenal oleh banyak kalangan karena hikayat ini telah melegenda sebagai pahlawan Melayu pada masa pemerinatahan Sultan Melaka abad ke-15. Dengan kepopuleran Hikayat Hang Tuah maka perlu dikaji segi kebahasaan yang membangun karya sastra tersebut. Salah satu bidang kebahasaan yang dapat digunakan untuk mengkaji ialah sintaksis.

Pengkajian hikayat melalui segi kebahasaan dapat dilakukan dengan cara melepaskan bagian-bagian kebahasaan di dalam hikayat menjadi bagian yang lebih kecil, seperti kalimat, klausa, dan frasa. Pengkajian bahasa dalam hikayat sangat diperlukan untuk membantu pembaca memahami hikayat secara menyeluruh. Ramlan menyatakan bahwa pengkajian bahasa membicarakan mengenai pengaturan dan hubungan katakata dalam membentuk frasa, klausa, dan kalimat (2005:139).

Sintaksis merupakan studi gramatikal antarkata yang menganalisis struktur satuan bahasa yang lebih besar dari kata, mulai dari frasa hingga kalimat (Sihombing dan Kentjono, 2005: 122). Kridalaksana (2008:223) mengungkapkan bahwa sintaksis merupakan bagian dari subsistem bahasa yang mencakup pengaturan dan hubungan antara kata dengan kata, atau dengan satuan-satuan yang lebih besar dalam bahasa. Verhaar (2008:161) menganggap bahwa sintaksis membahas hubungan gramatikal antarkata dalam kalimat.

Kalimat dipahami sebagai satuan bahasa yang secara relatif berdiri sendiri, mempunyai pola intonasi final dan secara aktual maupun potensial terdiri atas klausa (Kridalaksana, 2008: 92). Klausa juga dibatasi sebagai satuan gramatikal yang berupa kelompok kata yang sekurangkurangnya terdiri atas subjek dan predikat yang memiliki potensi menjadi kalimat (Kridalaksana, 2008:110). Frasa ialah satuan bahasa yang terdiri atas dua kata atau lebih yang tidak melampaui batas fungsi (Ramlan, 2005:121). Artinya, frasa selalu terdiri atas dua kata atau lebih. Sebagai tambahan, frasa juga diartikan sebagai satuan lingual yang merupakan gabungan sintaksis dua kata atau lebih, namun bukan konstruksi subjek-predikat atau klausa (Surono, 2014:19). Sejatinya frasa merupakan gabungan kata yang tidak memiliki predikat atau tidak memiliki kata kerja.

Mengingat pentingnya kedudukan dan fungsi Hikayat Hang Tuah yang telah disebutkan di atas, hikayat perlu dipahami secara me- 
nyeluruh. Salah satu cara untuk mencapai tujuan tersebut ialah dengan mengadakan penelitian terhadap aspek kebahasaan. Aspek kebahasaan Hikayat Hang Tuah yang akan diteliti, yaitu "Unsur Pembentuk Frasa Eksosentris dalam Hikayat Hang Tuah". Keraf (1984:138) menyatakan bahwa frasa merupakan satuan konstruksi yang terdiri dari dua kata atau lebih yang membentuk satu kesatuan. Pendapat tersebut didukung oleh Chaer (2012:222) yang mendefinisikan frasa sebagai satuan gramatikal yang berupa gabungan kata yang sifatnya nonpredikatif, atau disebut juga dengan gabungan kata yang mengisi salah satu fungsi sintaksis pada kalimat.

Unsur pembentuk frasa perlu dikaji untuk melihat konstruksi dari dua kata atau lebih yang membangun setiap bagian dari Hikayat Hang Tuah. Pemilihan satuan kebahasaan terutama pada frasa merupakan satuan kebahasaan yang mendasar dalam tataran sintaksis untuk membentuk kesatuan cerita yang dapat dipahami oleh pembaca. Apabila unsur pembentuk frasa dalam Hikayat Hang Tuah bersifat tidak gramatikal, pembaca akan sulit memahami cerita bahkan tidak mengetahui isi dari cerita Hikayat Hang Tuah. Selain itu, unsur pembentuk frasa dapat menunjukkan kekhasan frasa yang muncul dalam Hikayat Hang Tuah.

Ramlan (2005:141) mengungkapkan bahwa terdapat dua jenis frasa, yaitu (1) frasa endosentris dan (2) frasa eksosentris. Frasa endosentris ialah frasa yang mempunyai distribusi yang sama dengan unsurnya, baik dari semua unsurnya maupun salah satu dari unsurnya. Pendapat ini didukung oleh Tarigan (1986:96) yang menyatakan frasa endosentris adalah frasa yang berhulu, yang berpusat, yang mempunya fungsi yang sama dengan hulunya. Contoh frasa yang endosentris, seperti frasa dua orang mahasiswa mempunyai distribusi yang sama dengan unsurnya, baik dengan unsur dua orang maupun dengan unsur mahasiswa. Jenis lain dari frasa endosentris ialah frasa eksosentris. Frasa eksosentris merupakan frasa yang tidak mempunyai distribusi yang sama dengan unsurnya yang tidak berhulu dan tidak berpusat. Contohnya, yaitu frasa di perpustakaan, frasa tersebut tidak mempunya distribusi yang sama dengan semua unsurnya.

Penelitian ini melihat unsur pembentuk frasa dari jenis frasa eksosentris karena frasa eksosentris yang tidak berhulu dan tidak berpusat akan mampu menunjukkan kekhasan frasa yang membangun cerita Hikayat Hang Tuah. Jenis frasa eksosentris akan menunjukkan unsur- unsur yang membentuk satuan kebahasaan dalam Hikayat Hang Tuah. Apabila salah satu unsur dalam satuan kebahasaan berupa frasa eksosentris tersebut tidak terpenuhi, maka satuan kebahasaan lain berupa klausa bahkan kalimat akan berisfat tidak gramatikal. Hal ini akan menyebabkan Hikayat Hang Tuah tidak dapat dipahami oleh pembaca.

Penelitian-penelitian sebelumnya yang berkaitan dengan penelitian ini, yaitu penelitian yang dilakukan oleh Aridawati (2012) mengenai perluasan frasa tunggal dengan tipe eksosentris pada Bahasa Bali. Penelitian ini menunjukkan bahwa perluasan frasa tunggal tipe eksosentris dalam Bahasa Bali dibagi menjadi tiga, yaitu: (1) perluasan frasa tunggal eksosentris yang objektif, (2) perluasan frasa tunggal eksosentris yang direktif, dan (3) perluasan frasa tunggal eksosentris yang predikatif. Ardianto (2017) juga melakukan pengkajian mengenai penggunaan struktur frasa eksosentris direktif dan fungsinya dalam novel Negeri 5 Menara. Dari pengkajian tersebut dapat diketahui bahwa terdapat frasa eksosentris direktif yang dikaji berdasarkan pola struktur dan maknanya dalam novel Negeri 5 Menara. Makna tempat yang paling sering muncul adalah makna tempat posisional. Hal ini sesuai dengan banyaknya pola yang paling sering muncul yaitu preposisi dasar (di)+Nomina. Hal ini disebabkan makna frasa eksosentris direktif ditentukan dari preposisi yang digunakannya.

Selain penelitian yang berkaitan dengan frasa eksosentris, terdapat penelitian-penelitian yang berkaitan dengan bahasa Melayu sebagai bahasa yang digunakan dalam hikayat. Penelitian mengenai sintaksis pada Hikayat Tabut telah dilakukan oleh Afrita (2012) yang menunjukkan bahwa terdapat penyimpangan terhadap tulisan teks Hikayat Tabut pada penggunaan huruf, penulisan huruf, pemberian tanda saksi, dan penulisan kata dan kata ulang. Dom (2016) menunjukkan peranan adjung dalam bahasa Melayu. Dalam bahasa Melayu, penerang lokasi, penerang adjektif dan peranan penegasan merupakan adjung yang mampu mengubah SBK dalam bahasa Melayu. Leksikal kausatif dalam tata bahasa Melayu tidak hanya menekankan makna yang dibawa oleh kata kerja bersama imbuhan. Namun demikian, pengintepretasiannya dapat menjelaskan struktur dalam argumen kausatif kepada bentuk yang lebih terperinci (Jamilah \& Maslida, 2018). Selain itu, kalimat tanya dalam bahasa Melayu juga telah diteliti oleh Hafrianti \& Mulyadi (2018). Struktur internal kalimat 
tanya bahasa Melayu dialek Tamiang dibangun oleh specifier, complemen, dan adverbia. Ada pun specifier diduduki oleh NP, complemen diduduki oleh auxiliary, PP, atau NP, sedangkan adverbia dapat diduduki oleh PP atau NP.

Berdasarkan penelitian-penelitian yang telah ditemukan sebelumnya, belum ada penelitian yang membahas mengenai unsur frasa eksosentris dalam sebuah hikayat. Hal baru dan berbeda dalam penelitian ini ialah penelitian ini mengungkap segi kebahasaan terutama dalam bidang sintaksis pada karya sastra, yaitu Hikayat Hang Tuah. Selain itu, unsur pembangun dalam cerita Hikayat Hang Tuah dilihat dari tiga jenis frasa eksosentris, yaitu frasa eksosentris direktif, nondirektif, dan konektif. Oleh karena itu, penulis tertarik meneliti secara khusus tentang "Unsur Pembentuk Frasa Eksosentris dalam Hikayat Hang Tuah". Penelitian ini perlu dilakukan karena dalam sebuah karya sastra berupa Hikayat Hang Tuah perlu diketahui kekhasan unsur pembentuk frasa eksosentris yang dimunculkan untuk menjadikan cerita di dalamnya bersifat gramatikal sehingga dapat dipahami oleh pembaca. Selain itu, bahasa sebagai pembangun sebuah karya sastra dapat dipahami secara lebih menyeluruh bagi penikmat atau pembacanya.

Permasalahan yang dibahas dalam penelitian ini, yaitu unsur pembentuk frasa eksosentris direktif, unsur pembentuk frasa eksosentris nondirektif, dan unsur pembentuk frasa eksosentris konektif dalam Hikayat Hang Tuah. Tujuan khusus dari penelitian ini adalah mendeskripsikan unsur pembentuk frasa eksosentris dalam Hikayat Hang Tuah. Tujuan umum penelitian ini adalah meningkatkan wawasan tentang kearifankearifan lokal yang ada di dalam Hikayat Hang Tuah.

\section{METODE}

Jenis penelitian deskriptif kualitatif digunakan dalam penelitian ini. Penelitian jenis ini digunakan untuk mendeskripsikan gejala bahasa secara cermat dan teliti berdasarkan fakta-fakta kebahasaan. Gejala kebahasaan tersebut diklasifikasikan atas dasar tujuan penelitian yang hendak dicapai, kemudian dianalisis untuk menemukan unsur frasa eksosentris.

Populasi dalam penelitian ini, yakni semua bentuk unsur pembentuk frasa eksosentris yang diperoleh dari data pustaka. Pengambilan sampel dilakukan dengan menggunakan teknik sampel purposif (pusposive sampling). Teknik ini dimaksudkan sebagai bentuk pengambilan sampel sesuai kebutuhan penelitian dengan cara mengumpulkan sebagian (tidak semua) dari populasi. Populasi dalam penelitian ini berupa frasa yang mengalami proses sintaksis, yaitu unsur pembentuk frasa eksosentris direktif, nondirektif, dan konektif yang tentunya dapat mewakili keseluruhan data yang ada.

Frasa dalam Hikayat Hang Tuah merupakan objek dalam penelitian ini. Lebih lanjut, data dalam penelitian berupa kalimat yang mengandung frasa eksosentris dalam Hikayat Hang Tuah. Sumber data dalam penelitian ini adalah dokumen berupa buku Hikayat Hang Tuah .

Teknik pengumpulan data yang digunakan dalam penelitian ini adalah teknik observasi. Artinya, peneliti mengamati secara langsung objek penelitian dengan menggunakan teknik dan prosedur dalam penelitian. Peneliti langsung mengamati setiap unsur bahasa yang muncul dalam Hikayat Hang Tuah. Data yang terkumpul selanjutnya diklasifikasikan sesuai dengan keperluan analisis.

Berdasarkan masalah yang telah dirumuskan dengan tujuan dalam penelitian ini, metode dalam penelitian ini adalah metode agih. Alat penentu metode ini didasarkan atas bagian dari bahasa itu sendiri. Teknik dasar metode agih berupa teknik bagi unsur langsung. Cara kerja teknik ini ialah membagi satuan lingual pada data menjadi beberapa bagian atau unsur dan dianggap sebagai bagian yang langsung membentuk satuan lingual yang dimaksud. Peneliti membagi satuan lingual berupa kalimat menjadi satuan lingual frasa eksosentris yang dimaksud. Teknik lanjutan yang digunakan dalam metode agih ialah teknik lesap dengan melesapkan unsur tertentu satuan lingual yang bersangkutan. Frasa eksosentris yang terdapat dalam kalimat dilesapkan untuk membuktikan kegramatikalan dari unsur pembentuk frasa eksosentris dalam kalimat.

\section{HASIL DAN PEMBAHASAN}

\section{Hasil}

Terdapat tiga jenis frasa eksosentris, yaitu frasa eksosentris direktif, nondirektif, dan konektif. Unsur pembentuk frasa eksosentris dapat dilihat pada uraian berikut.

Frasa Eksosentris Direktif Preposisi+Nomina

Preposisi+Nomina 
Frasa eksosentris direktif yang berunsur preposisi+nomina, dapat dijelaskan melalui data (1).

(1) Syahdan apabila baginda ke luar, dihadap oleh segala raja-raja dan menteri hulubalang, maka beberapa pedang yang sudah terhunus kepada kiri kanan baginda itu, dan beberapa puluh bentara yang memangku pedang yang berikatkan emas, bertatahkan ratna mutu manikam (HHT, 2010: 3).

'Ketika baginda keluar, berhadapan dengan raja dan menteri perang, beberapa pedangnya ditarik ke tangan kanannya, dan beberapa bentara yang memegang pedang berikat emas, bertatahkan ratna mutu manikam (HHT, 2010: 3).'

Dalam kalimat (1) terdapat frasa ke luar, yang terdiri atas dua unsur langsung. Unsur ke sebagai unsur pertama merupakan preposisi dan luar sebagai unsur langsung kedua berupa nomina. Masing-masing unsur dalam frasa tersebut tidak berdistribusi paralel. Hal tersebut dapat dilihat dalam bukti berikut.

(a) Syahdan apabila baginda ke luar,

(b) *Syahdan apabila baginda ke (tidak gramatikal)

(c) *Syahdan apabila baginda luar (tidak gramatikal)

Setiap unsur frasa ke luar tidak memiliki distribusi paralel, tetapi memiliki distribusi komplementer. Hubungan antarunsur frasa ke luar bersifat bilateral dengan unsur pertama berupa preposisi ke dan unsur kedua berupa nomina luar.

(2) Maka daripada anak cucu baginda itu, akan menjadi raja besar-besar pada akhir zaman (HHT, 2010:3).

'Maka dari keturunannya, ia akan menjadi raja besar di akhir zaman (HHT, 2010:3).'

Data (2) tersebut muncul frasa eksosentris direktif berupa frasa pada akhir zaman. Unsur preposisi pada merupakan unsur pertama dalam frasa tersebut. Unsur kedua frasa tersebut berupa nomina, yaitu akhir zaman. Masing-masing unsur tersebut tidak dapat dipisahkan dan bersifat bilateral antara preposisi dan nomina. Hal tersebut dibuktikan melalui pelesapan berikut.

(a) Maka daripada anak cucu baginda itu, akan menjadi raja besar-besar pada akhir zaman.

(b) *Maka daripada anak cucu baginda itu, akan menjadi raja besar-besar pada. (tidak gramatikal) (c) *Maka daripada anak cucu baginda itu, akan menjadi raja besar-besar akhir zaman. (tidak gramatikal)

Frasa eksosentris direktif juga ditemukan dalam data (3).

(3) Tatkala mesralah kasih dan sayang, maka Sang Pertala Dewa pun bertitah kepada tuan puteri, "Ayuhai adinda-kakanda, pintalah kemala hikmat itu akan kakanda ini." (HHT, 2010:6)

'Ketika Anda mencintai dan menyayangi, pembicaraan Sang Pertala Dewa memberi tahu sang putri, "Ayo, adinda-kakanda, tolong keluarkan kebijaksanaan ini dari sini." (HHT, 2010: 6)'

Terdapat frasa eksosentris direktif dalam kalimat tersebut, yaitu pada frasa kepada tuan puteri. Unsur pertama berupa preposisi ialah kepada, sedangkan unsur kedua berupa tuan puteri merupakan nomina. Frasa tersebut merupkan frasa eksosentris direktif karena tidak berdistribusi paralel dengan unsur-unsurnya. Hal tersebut dapat dilihat dalam bukti berikut.

(a) Tatkala mesralah kasih dan sayang, maka Sang Pertala Dewa pun bertitah kepada tuan puteri, "Ayuhai adinda - kakanda, pintalah kemala hikmat itu akan kakanda ini."

(b) *Tatkala mesralah kasih dan sayang, maka Sang Pertala Dewa pun bertitah kepada, "Ayuhai adinda - kakanda, pintalah kemala hikmat itu akan kakanda ini." (tidak gramatikal)

(c) *Tatkala mesralah kasih dan sayang, maka Sang Pertala Dewa pun bertitah tuan puteri, "Ayuhai adinda - kakanda, pintalah kemala hikmat itu akan kakanda ini." (tidak gramatikal)

Bentuk frasa eksosentris direktif yang ditemukan dalam Hikayat Hang Tuah juga menunjukkan adanya unsur-unsur yang berdistribusi komplementer sehingga apabila unsur yang lain tidak muncul dalam frasa tersebut maka tidak berterima secara gramatikal. Hal tersebut dapat dilihat dalam data (4).

(4) Adapun segala orang yang duduk di sungai Duyung, mendengar warta raja Bintan itu (HHT, 2010:22).

'Semua orang duduk di sungai Duyung, mendengar berita tentang raja Bintan (HHT, 2010: 22).'

Frasa eksosentris direktif dapat dibuktikan melalui pelesapan salah satu unsurnya dalam se- 
buah kalimat. Dalam pembuktian tersebut dapat diketahui bahwa preposisi di berkomplementer dengan nomina sungai Duyung.

(a) Adapun segala orang yang duduk $d i$ sungai Duyung, mendengar warta raja Bintan itu.

(b) *Adapun segala orang yang duduk di, mendengar warta raja Bintan itu. (tidak gramatikal)

(c) *Adapun segala orang yang duduk sungai Duyung, mendengar warta raja Bintan itu. (tidak gramatikal)

Selain data tersebut, preposisi oleh sebagai unsur pertama frasa eksosentris direktif juga ditemukan dalam frasa oleh duli yang berkomplementer dengan nomina duli sebagai unsur kedua frasa tersebut. Hal tersebut dapat dilihat dari data (5).

(5) Maka kata Hang Tuah dan Hang Jebat, "Cih, si celaka, tiadakah engkau tahu aku hulubalang di tanah Bintan ini? Aku dititahkan oleh duli yang dipertuan akan membuang orang durhaka ini (HHT, 2010:34).

'Jadi Hang Tuah dan Hang Jebat berkata, "Cih, si celaka, apakah Anda mengenal saya sebagai seorang prajurit di tanah Bintan? Saya diberitahu oleh raja bahwa ia akan mencampakkan orang-orang ini (HHT, 2010: 34).'

Frasa oleh duli tidak dapat dipisahkan atau dihilangkan satu sama lainnya. Inilah yang menunjukkan bahwa frasa eksosentris direktif muncul dalam Hikayat Hang Tuah. Hal ini dapat dilihat melalui pembuktian berikut.

(a) Maka kata Hang Tuah dan Hang Jebat, "Cih, si celaka, tiadakah engkau tahu aku hulubalang di tanah Bintan ini? Aku dititahkan oleh duli yang dipertuan akan membuang orang durhaka ini.

(b) *Maka kata Hang Tuah dan Hang Jebat, "Cih, si celaka, tiadakah engkau tahu aku hulubalang di tanah Bintan ini? Aku dititahkan oleh yang dipertuan akan membuang orang durhaka ini. (tidak gramatikal)

(c) *Maka kata Hang Tuah dan Hang Jebat, "Cih, si celaka, tiadakah engkau tahu aku hulubalang di tanah Bintan ini? Aku dititahkan duli yang dipertuan akan membuang orang durhaka ini. (tidak gramatikal)
Frasa Eksosentris Nondirektif Partikel/Kata Sebutan+Adjektiva

Partikel/kata sebutan+Adjektiva

Frasa eksosentris nondirektif memiliki unsur pertama berupa partikel/kata sebutan dan unsur kedua berupa adjektiva. Hal ini dapat dijelaskan melalui data (6).

(6) Maka kata Hang Tuah dan Hang Jebat, "Cih, si celaka, tiadakah engkau tahu aku hulubalang di tanah Bintan ini? Aku dititahkan oleh duli yang dipertuan akan membuang orang durhaka ini (HHT, 2010:34).

'Jadi Hang Tuah dan Hang Jebat berkata, "Cih, si celaka, apakah Anda mengenal saya sebagai seorang prajurit di tanah Bintan? Saya diberitahu oleh raja bahwa ia akan mencampakkan orang-orang ini (HHT, 2010: 34).'

Dalam data (6) terdapat frasa eksosentris nondirektif si celaka. Frasa tersebut termasuk ke dalam frasa eksosentris karena tidak memiliki inti/pusat. Apabila salah satu unsur dari frasa tersebut dihilangkan maka akan bersifat tidak gramatikal. Hal ini dapat dilihat dari pemisahan berikut.

(a) Maka kata Hang Tuah dan Hang Jebat, "Cih, si celaka, tiadakah engkau tahu aku hulubalang di tanah Bintan ini? Aku dititahkan oleh duli yang dipertuan akan membuang orang durhaka ini.

(b) *Maka kata Hang Tuah dan Hang Jebat, "Cih, si, tiadakah engkau tahu aku hulubalang di tanah Bintan ini? Aku dititahkan oleh duli yang dipertuan akan membuang orang durhaka ini. (tidak gramatikal)

(c) *Maka kata Hang Tuah dan Hang Jebat, "Cih, celaka, tiadakah engkau tahu aku hulubalang di tanah Bintan ini? Aku dititahkan oleh duli yang dipertuan akan membuang orang durhaka ini. (tidak gramatikal)

Dapat dilihat bahwa unsur pertama dalam frasa eksosentris nondirektif si celaka ialah si sebagai partikel/ kata sebutan. Unsur kedua dalam frasa tersebut adalah celaka yang merupakan adjektiva. Apabila salah satu unsur tidak terpenuhi, maka frasa tersebut tidak gramatikal. 
Frasa Eksosentris Nondirektif Partikel/Kata Sebutan+Nomina

Partikel/kata sebutan+Nomina

Unsur frasa eksosentris nondirektif berupa partikel/kata sebutan+nomina dapat dilihat dalam data (7) dan (8).

(7) Adapun Sang Pertala Dewa itu tahu akan dirinya akan beroleh anak (HHT, 2010:3).

'Sang Pertala Dewa tahu bahwa ia akan mendapatkan anak (HHT, 2010: 3).'

(8) Maka anakanda baginda itu pun disambut oleh baginda serta dinamai oleh baginda Sang Purba (HHT, 2010:7).

'Putranya juga disambut oleh baginda dan menamainya Sang Purba (HHT, 2010: 7).'

Frasa Sang Pertala Dewa memiliki unsur pertama berupa partikel/kata sebutan Sang dan unsur kedua berupa nomina Pertala Dewa. Frasa Sang Purba memiliki unsur kedua berupa nomina Purba. Frasa Sang Pertala Dewa dan Sang Purba tersebut tidak memiliki unsur D (Diterangkan) di dalamnya. Frasa eksosentris nondirektif ini terbentuk dari partikel/kata sebutan dan nomina yang sama-sama berfungsi sebagai unsur $\mathrm{M}$ (Menerangkan). Hal ini dapat dibuktikan melalui pelesapan frasa tersebut.

(a) (kalimat 7) Adapun Sang Pertala Dewa itu tahu akan dirinya akan beroleh anak.

(kalimat 8) Maka anakanda baginda itu pun disambut oleh baginda serta dinamai oleh baginda Sang Purba.

(b) (kalimat 7) Adapun Pertala Dewa itu tahu akan dirinya akan beroleh anak.

(kalimat 8)Maka anakanda baginda itu pun disambut oleh baginda serta dinamai oleh baginda Purba.

(c) (kalimat 7) *Adapun Sang itu tahu akan dirinya akan beroleh anak. (tidak gramatikal)

(kalimat 8) *Maka anakanda baginda itu pun disambut oleh baginda serta dinamai oleh baginda Sang. (tidak gramatikal)

Hikayat Hang Tuah menunjukkan adanya frasa eksosentris nondirektif seperti data (9).

(9) Maka baginda pun bertitah kepada perdana menteri, suruh memanggil segala ahlunnujum dan segala sasterawan (HHT, 2010:3).

'Jadi baginda juga mengatakan kepada perdana menteri, untuk memanggil semua ahlunnujum dan semua sastra (HHT, 2010: $3)$.'

Data (9) menunjukkan bahwa dalam Hikayat Hang Tuah terdapat frasa eksosentris nondirektif berupa segala ahlunnujum. Frasa tersebut terdiri dari dua unsur pembentuk, yaitu segala sebagai unsur partikel/kata sebutan dan ahlunnujum sebagai unsur nomina. Unsur segala digunakan sebagai unsur yang mengkhususkan nomina dalam frasa tersebut. Oleh karena itu, apabila unsur nomina dilesapkan maka akan bersifat tidak gramatikal. Hal tersebut dapat dibuktikan sebagai berikut.

(a) Maka baginda pun bertitah kepada perdana menteri, suruh memanggil segala ahlunnujum dan segala sasterawan.

(b) Maka baginda pun bertitah kepada perdana menteri, suruh memanggil ahlunnujum dan segala sasterawan.

(c) *Maka baginda pun bertitah kepada perdana menteri, suruh memanggil segala dan segala sasterawan. (tidak gramatikal)

Data lain yang mengandung frasa eksosetris nondirektif dalam Hikayat Hang Tuah terdapat pada data (10) dan (11) sebagai berikut.

(10) Jika Si Tuah gerangan membawa titah tuannya itu, sehingga putih tulangnya tiada putih mata (HHT, 2010:104).

'Jika si Tuah membawa perintah tuannya, sehingga putih tulangnya tiada putih mata (HHT, 2010: 104).'

(11) Belum sempat duduk maka titah Raja Melaka, "Hai bentara, segera buang Si Jaya Nantaka itu. Demi Allah, tiada aku melihat mukanya lagi!"( HHT, 2010:76)

'Belum sempat duduk Raja Melaka berkata, "Hai bentara, segera buang si Jaya Nantaka, karena Demi Allah, saya tidak ingin melihat wajahnya lagi!" (HHT, 2010: 76)'

Frasa Si Tuah dan Si Jaya Nantaka dalam kalimat (10) dan (11) merupakan frasa eksosentris nondirektif. Frasa tersebut terdiri dari dua unsur, yaitu unsur partikel/kata sebutan $S i$ dan unsur nomina berupa Tuah (kalimat 10) dan $\mathrm{Ja}$ ya Nantaka (kalimat 11). Apabila unsur nomina dilesapkan dalam frasa tersebut maka akan bersifat tidak gramatikal. Hal ini dapat dibuktikan melalui pelesapan berikut.

(a) (kalimat 10) Jika Si Tuah gerangan membawa titah tuannya itu, sehingga putih tulangnya tiada putih mata.

(kalimat 11) Belum sempat duduk maka titah Raja Melaka, "Hai bentara, segera 
buang Si Jaya Nantaka itu. Demi Allah, tiada aku melihat mukanya lagi!"

(b) (kalimat 10) Jika Tuah gerangan membawa titah tuannya itu, sehingga putih tulangnya tiada putih mata.

(kalimat 11) Belum sempat duduk maka titah Raja Melaka, "Hai bentara, segera buang Jaya Nantaka itu. Demi Allah, tiada aku melihat mukanya lagi!"

(c) (kalimat 10) *Jika Si gerangan membawa titah tuannya itu, sehingga putih tulangnya tiada putih mata. (tidak gramatikal)

(kalimat 11) *Belum sempat duduk maka titah Raja Melaka, "Hai bentara, segera buang $S i$ itu. Demi Allah, tiada aku melihat mukanya lagi!" (tidak gramatikal)

\section{Frasa Eksosentris Konektif Kata Penghubung+Verba}

\section{Kata penghubung+Verba}

Dalam Hikayat Hang Tuah ditemukan frasa eksosentris konektif yang menunjukkan unsur kata penghubung+verba dalam frasanya. Hal ini dapat dilihat dari data (12).

(12) Maka anaknya itulah akan menjadi raja di Bukit Seguntang (HHT, 2010:3).

'Maka putranya akan menjadi raja di Bukit Seguntang (HHT, 2010: 3).'

Data (12) tersebut menunjukkan adanya frasa eksosentris konektif, yaitu akan menjadi. Frasa tersebut memiliki unsur pertama berupa kata penghubung akan dan unsur kedua menjadi merupakan verba. Frasa tersebut tidak memiliki unsur D (Diterangkan) di dalamnya. Hal ini karena frasa akan menjadi terbentuk dari gabungan dua kata yang sama-sama berfungsi sebagai unsur M (Menerangkan). Kedua unsur dalam frasa akan menjadi merupakan unsur yang bersifat distribusi komplementer. Apabila salah satu unsurnya tidak terpenuhi maka akan bersifat tidak gramatikal. Hal ini dapat dilihat melalui bukti berikut.

(a) Maka anaknya itulah akan menjadi raja di Bukit Seguntang.

(b) *Maka anaknya itulah menjadi raja di Bukit Seguntang. (tidak gramatikal)

(c) *Maka anaknya itulah akan raja di Bukit Seguntang. (tidak gramatikal)
Data lain yang ditemukan dalam Hikayat Hang Tuah terdapat pada kalimat (13) berikut.

(13) Sekali peristiwa, maka baginda bertitah kepada segala menteri hulubalang, "Hai tuan sekalian, baiklah tuan sekalian berlengkap, esok hari kita hendak turun ke pulau Biram Dewa, hendak pergi bermain-main dan berburu." (HHT, 2010:5)

'Sekali waktu, dia berkata kepada semua menteri raja, "Hai tuan, mari kita semua selesai, besok kita akan pergi ke pulau Biram Dewa, untuk bermain dan berburu." (HHT, 2010: 5)'

Frasa hendak pergi dalam kalimat (13) memiliki unsur kata penghubung dan verba. Unsur pertama berupa kata penghubung terdapat pada hendak dan unsur kedua pergi merupakan verba. Kedua unsur tersebut tidak memiliki unsur inti untuk D (Diterangkan) tetapi keduanya berfungsi sebagai unsur M (Menerangkan). Hal ini yang menunjukkan bahwa frasa hendak pergi tidak dapat dihilangkan salah satu unsurnya. Apabila salah satu unsurnya dilesapkan, maka akan bersifat tidak gramatikal. Bukti bahwa kedua unsur dalam frasa hendak pergi tidak dapat dilesapkan dapat dilihat dari pemilahan berikut.

(a) Sekali peristiwa, maka baginda bertitah kepada segala menteri hulubalang, "Hai tuan sekalian, baiklah tuan sekalian berlengkap, esok hari kita hendak turun ke pulau Biram Dewa, hendak pergi bermain-main dan berburu."

(b) *Sekali peristiwa, maka baginda bertitah kepada segala menteri hulubalang, "Hai tuan sekalian, baiklah tuan sekalian berlengkap, esok hari kita hendak turun ke pulau Biram Dewa, hendak bermain-main dan berburu." (tidak gramatikal)

(c) *Sekali peristiwa, maka baginda bertitah kepada segala menteri hulubalang, "Hai tuan sekalian, baiklah tuan sekalian berlengkap, esok hari kita hendak turun ke pulau Biram Dewa, pergi bermain-main dan berburu." (tidak gramatikal)

Data (14) juga menunjukkan adanya frasa eksosentris konektif yang salah satu unsurnya sebagai penghubung atau konektor unsur lain.

(14) Terlalu elok rupanya, seperti empat belas hari bulan Maka baginda pun segera 
menghampiri tuan puteri itu (HHT, 2010:5).

'Itu sangat indah, seperti empat belas hari dalam sebulan. Jadi dia segera mendekati sang putri (HHT, 2010: 5).'

Unsur-unsur frasa segera menghampiri dalam kalimat (14) memiliki unsur pertama kata penghubung segera dan unsur kedua berupa verba menghampiri. Kedua unsur dalam frasa tersebut tida berdistribusi paralel, namun memiliki distribusi komplementer. Semua unsur dalam frasa eksosentr konektif tidak dapat dilesapkan salah satunya. Hal ini dapat dilihat dari bukti berikut.

(a) Terlalu elok rupanya, seperti empat belas hari bulan Maka baginda pun segera menghampiri tuan puteri itu.

(b) *Terlalu elok rupanya, seperti empat belas hari bulan Maka baginda pun segera tuan puteri itu. (tidak gramatikal)

(c) *Terlalu elok rupanya, seperti empat belas hari bulan Maka baginda pun menghampiri tuan puteri itu. (tidak gramatikal)

Ketika konektor/ penghubung dilesapkan seperti bukti dalam kalimat (c) maka akan mempengaruhi makna kalimat tersebut. Penghubung segera merupakan kekhususan dalam penyampaian verba menghampiri. Hal ini yang menyebabkan setiap unsur dalam frasa tidak dapat dilesapkan.

\section{Pembahasan}

Dalam penelitian ini ditemukan jenis frasa eksosentris dalam Hikayat Hang Tuah ialah frasa eksosentris direktif, nondirektif, dan konektif. Keberagaman jenis frasa eksosentris dalam Hikayat Hang Tuah menunjukkan temuan baru bahwa dalam sebuah karya sastra tidak hanya pada frasa eksosentris direktif saja. Hal ini menunjukkan bahwa satuan kebahasaan sebagai unsur pembangun sebuah karya sastra memerluka jenis frasa eksosentris direktif, nondirektif, dan konektif. Dengan demikian, setiap unsur pembentuk dalam frasa eksosentris direktif, nondirektif, dan konektif tidak dapat dipisahkan satu sama lain. Frasa eksosentris sebagai salah satu unsur pembangun kebahasaan dalam Hikayat Hang Tuah dibutuhkan untuk menunjang alur cerita. Berdasarkan analisis secara keseluruhan, unsur pembentuk frasa eksosentris dalam Hikayat Hang Tuah yang telah ditemukan pada penelitian ini menyempurnakan hasil penelitian Ardianto (2017) yang menyatakan bahwa kecen- derungan lebih banyaknya frasa eksosentris direktif yang bermakna tempat di dalam sebuah novel karena pengarang banyak membutuhkan kehadiran frasa eksosentris direktif bermakna tempat untuk memperjelas latar ceritanya.

Berdasarkan perluasan frasa, penelitian ini menunjukkan adanya unsur pembentuk frasa eksosentris dalam Hikayat Hang Tuah yang telah ditemukan dalam frasa eksosentris direktif berupa preposisi+nomina, sedangkan unsur pembentuk frasa eksosentris nondirektif, yaitu partikel/kata sebutan+adjektiva dan partikel/kata sebutan+nomina. Selain itu terdapat unsur pembentuk frasa eksosentris konektif ialah kata penghubung+verba. Hasil penelitian sejalan dengan Aridawati (2012) yang menjelaskan bahwa perluasan frasa tunggal tipe eksosentris dalam bahasa Bali dibagi menjadi tiga, yaitu: (1) perluasan frasa tunggal eksosentris yang objektif, (2) perluasan frasa tunggal eksosentris yang direktif, dan (3) perluasan frasa tunggal eksosentris yang predikatif.

Unsur pembentuk frasa eksosentris memiliki tiga jenis, yaitu frasa eksosentris direktif, nondirektif, dan konektif. Seluruh jenis unsur pembentuk frasa eksosentris menunjukkan bahwa setiap unsur tidak memiliki distribusi paralel, tetapi memiliki distribusi komplementer sehingga apabila unsur yang lain tidak muncul dalam frasa tersebut maka tidak berterima. Hubungan antar unsur frasa bersifat mitual atau bilateral dengan unsur pertama dan unsur kedua. Masingmasing unsur tersebut tidak dapat dipisahkan.

Frasa eksosentris direktif dalam Hikayat Hang Tuah memiliki unsur pembentuk berupa preposisi+nomina, masing-masing unsur tersebut tidak dapat dipisahkan agar tetap bersifat gramatikal. Unsur pembentuk frasa yang lain berupa partikel/kata sebutan+adjektiva dan parti$\mathrm{kel} /$ kata sebutan+nomina yang terdapat dalam jenis frasa eksosentris nondirektif. Masing-masing unsur pembentuk dalam frasa tersebut tidak memiliki inti/pusat. Apabila salah satu unsur tidak terpenuhi, maka frasa tersebut tidak gramatikal. Frasa tersebut tidak memiliki unsur D (Diterangkan) di dalamnya. Frasa eksosentris nondirektif ini terbentuk dari partikel/kata sebutan dan nomina yang sama-sama berfungsi sebagai unsur M (Menerangkan). Selain itu, frasa eksosentris konektif memiliki unsur pembentuk berupa kata penghubung+verba. Kedua unsur dalam frasa tersebut berdistribusi komplementer. Ketika konektor/penghubung dilesapkan maka akan mempengaruhi makna kalimat tersebut. Penghubung merupakan kekhususan dalam 
penyampaian verba dan setiap unsur tersebut tidak dapat dilesapkan.

Unsur pembentuk frasa eksosentris sangat berpengaruh dalam Hikayat Hang Tuah. Hal ini didasarkan pada keberagaman isi dari Hikayat Hang Tuah. Alur cerita dalam Hikayat Hang Tuah sangat membutuhkan frasa eksosentris untuk menunjang isi cerita dalam hikayat tersebut. Unsur pembentuk frasa eksosentris direktif berupa preposisi+nomina dalam Hikayat Hang Tuah berkaitan dengan beragam lokasi atau tempat, yaitu Bintan, Jawa, tanah Melayu, Melaka, Majapahit, Gajah Mada, Inderapura, dan beragam tempat lain yang disinggahi tokoh dalam cerita. Dalam sebuah karya sastra khususnya Hikayat Hang Tuah, untuk menunjukkan lokasi atau tempat dalam cerita tidak dapat terlepas dari unsur kebahasaan yang paling dasar berupa frasa eksosentris direktif.

Selain jenis frasa eksosentris direktif, terdapat jenis frasa eksosentris nondirektif. Unsur pembentuk frasa eksosentris nondirektif berupa partikel/kata sebutan+adjektiva dan partikel/kata sebutan+nomina. Unsur pembentuk frasa ini, dalam Hikayat Hang Tuah muncul karena alur cerita tersebut memiliki banyak tokoh dan membutuhkan unsur pembentuk frasa eksosentris nondirektif. Hal tersebut dapat dilihat pada setiap bagian cerita yang memunculkan banyak tokoh dalam Hikayat Hang Tuah, yaitu Hang Tuah, Dang Merduwati, Hang Mahmud, Hang Jebat, Hang Kesturi, Hang Lekir, Hang Lekiu, Raja Bintan, orang-orang Jawa, orang-orang Melayu, Raja Melaka, Raja Muda, Raja Keling, Raja Majapahit, Patih Gajah Mada, Tun Teja, Megat Panji Alam, dan tokoh-tokoh lain yang ditunjukkan melalui frasa eksosentris nondirektif. Tanpa adanya unsur kebahasaan berupa frasa eksosentris nondirektif, maka tokoh-tokoh dalam Hikayat Hang Tuah tidak akan dapat ditunjukkan dengan kebahasaan yang gramatikal.

Jenis frasa eksosentris lainnya ialah frasa ekosentris konektif yang memiliki unsur pembentuk frasa berupa kata penghubung+verba. Unsur pembentuk frasa eksosentris jenis ini banyak menunjukkan hubungan antarperistiwa dalam Hikayat Hang Tuah. Beragam kegiatan atau tindakan Hang Tuah di setiap peristiwa atau kejadian dalam Hikayat Hang Tuah membutuhkan satuan kebahasaan frasa berupa frasa eksosentris konektif untuk menghubungkan kegiatan atau tindakan dalam peristiwa yang satu dengan yang lainnya. Peristiwa-peristiwa atau kejadian yang terdapat dalam alur cerita Hikayat Hang Tuah, yaitu perjalanan Hang Tuah sebagai se- orang laksamana yang diutus oleh Raja untuk menyerang ke Palembang, memerintahkan ke Tiongkok, Rum, Mahapahit, dan dia pernah pula naik haji. Dalam Hang Tuah terdapat banyak kegiatan atau tindakan yang membutuhkan frasa eksosentris konektif untuk menghubungkannya.

Makna frasa eksosentris dalam hikayat yang dominan muncul sebagai unsur pembentuk ialah frasa eksosentris direktif berupa preposisi+nomina. Hal ini berkaitan dengan Hikayat Hang Tuah yang banyak memunculkan lokasi atau tempat yang berbeda-beda sesuai dengan cerita dalam hikayat tersebut. Hang Tuah sebagai laksamana yang diutus oleh raja, berkelana menuju ke berbagai tempat sesuai perintah raja. Selain itu, frasa eksosentris konektif juga banyak muncul dalam Hikayat Hang Tuah karena telah banyak kegiatan atau tindakan dalam beragam peristiwa atau kejadian yang dilakukan oleh Hang Tuah atas perintah raja. Seluruh keberanian Hang Tuah dimunculkan dalam setiap frasa eksosentris konektif yang memiliki unsur pembentuk berupa kata penghubung+verba.

\section{PENUTUP}

Berdasarkan penelitian disimpulkan bahwa terdapat tiga jenis frasa eksosentris dalam Hikayat Hang Tuah. Jenis tersebut ialah frasa eksosentris direktif, frasa eksosentris non direktif, dan frasa eksosentris konektif. Unsur pembentuk masing-masing jenis frasa eksosentris dalam Hikayat Hang Tuah tidak dapat dipisahkan dan saling berdistribusi komplementer. Apabila salah satu unsur pembentuk dalam frasa dilesapkan maka akan bersifat tidak gramatikal. Unsur pembentuk jenis frasa eksosentris dalam Hikayat Hang Tuah ialah (1) frasa eksosentris direktif berupa preposisi+nomina; (2) frasa eksosentris nondirektif, yaitu partikel/kata sebutan+adjektiva dan partikel/kata sebutan+nomina; (3) frasa eksosentris konektif ialah kata penghubung+verba. Munculnya unsur pembentuk frasa eksosentris menunjukkan adanya kekayaan bahasa dalam Hikayat Hang Tuah. Frasa eksosentris direktif, nondirektif, dan konektif dibutuhkan untuk membangun cerita menjadi kesatuan yang utuh dan bersifat gramatikal. Tanpa adanya frasa eksosentris direktif, nondirektif, dan konektif dalam Hikayat Hang Tuah, maka tempat kejadian, tokoh, dan kegiatan atau tindakan setiap peristiwa dalam cerita tidak dapat tersampaikan dan tidak terpahami pembaca. Pemahaman unsur pembentuk frasa Hikayat Hang Tuah dapat meningkatkan keterbacaan naskah. 
164 RETORIKA: Jurnal Bahasa, Sastra, dan Pengajarannya, Volume 12, Nomor 2 Agustus 2019, hlm. 154-164

\section{UCAPAN TERIMA KASIH}

Penulis menyampaikan ucapan terima kasih kepada mitra bestari (reviewers) yang telah

\section{DAFTAR PUSTAKA}

Afrita, E. 2012. Hikayat Tabut (Suatu Tinjauan Filologi dan Sintaksis). Humanus. 11 (2):189200.

Ardianto, B. 2017. Penggunaan Struktur Frasa Eksosentris Direktif dan Fungsinya dalam Novel "Negeri 5 Menara" (A. Fuadi) dan Implikasinya dalam Pembelajaran Bahasa Indonesia di SMA. Aksis (Jurnal Pendidikan Bahasa dan Sastra Indonesia). Vol 1(1): 27-43.

Aridawati, I. A. P. 2012. Perluasan Frasa Tunggal Tipe Eksosentrik Bahasa Bali. Sawerigading, 18 (1):69-78.

Chaer, A. 2012. Linguistik Umum (Edisi Revisi). Jakarta: Rineka Cipta.

Dom, F. M., Sudirman, N., Ibrahim, N. A. 2016. Peranan Adjung dalam Bahasa Melayu: Suatu Analisis Tatabahasa Peranan dan Rujukan. Jurnal Melayu, 15 (1): 67-81.

Hafrianto, J. \& Mulyadi. 2018. Kalimat Tanya dalam Bahasa Melayu Dialek Tamiang. Litera, 17(2):186-201. memberikan komentar, saran, dan kritikan perbaikan terhadap naskah ini. Bantuan yang diberikan telah membantu penulis meningkatkan kualitas artikel ini.

Jamilah, N. \& Maslida. 2018. Representasi Argumen Struktur Konseptual bagi Kata Kerja Kausatif Bahasa Melayu dan Hubungannya dengan Sintaksis. Gema Online (Journal of Language Studies, 18 (4):143-167.

Keraf, G. 1984. Tata Bahasa Indonesia. Ende Flores: Nusa Indah.

Kridalaksana, H. 2008. Kamus Linguistik. Jakarta: Gramedia Pustaka Utama.

Ramlan. M. 2005. Sintaksis. Yogyakarta: CV. Karyono.

Schap, B. G. 2010. Hikayat Hang Tuah I. Jakarta: Pusat Bahasa

Sihombing, L. P. \& Kentjono, D. 2005. Sintaksis (Dalam Pesona Bahasa). Jakarta: Gramedia Pustaka Utama.

Surono. 2014. Analisis Frasa-Kalimat Bahasa Indonesia. Semarang: Gigih Pustaka Pribadi.

Tarigan, H. G. 1986. Pengajaran Sintaksis. Bandung: Angkasa.

Verhaar, J. W. M. 2008. Asas-Asas Linguistik Umum. Yogyakarta: Gadjah Mada University Press. 